\title{
GENETIC DISSIMILARITY AMONG THE PHYSIOCHEMICAL CHARACTERISTICS OF FRUIT FROM PEPPER ACCESSIONS
}

\author{
DISSIMILARIDADE GENÉTICA ENTRE ACESSOS DE PIMENTA PARA \\ CARACTERES FÍSICO-QUÍMICO DE FRUTO
}

\section{Gabriel Mascarenhas MACIEL ${ }^{1}$; Camila Soares de OLIVEIRA ${ }^{2}$; Ana Carolina Silva SIQUIEROLI ${ }^{3}$; Edmar Isaias de MELO ${ }^{4}$; Alisson Henrique Gama de OLIVEIRA ${ }^{2}$}

1. Professor, Doutor, Instituto de Ciências Agrárias - ICIAG, Universidade Federal de Uberlândia-UFU, Monte Carmelo, MG, Brasil. gabrielmaciel@ufu.br; 2. Discentes do curso de Agronomia, ICIAG - UFU, Monte Carmelo, MG, Brasil; 3. Professora, Doutora, Instituto de Genética e Bioquímica - INGEB - UFU, Monte Carmelo, MG, Brasil; 4. Professor, Doutora, Instituto de Química - IQ UFU, UFU, Monte Carmelo, MG, Brasil;

\begin{abstract}
The objective was to evaluate the genetic variability among pepper accessions al the physical and chemical characteristics of fruit. Pepper accesses are from the Germplasm Bank at the Federal University of Uberlandia Monte Carmelo Campus (Universidade Federal de Uberlândia-UFU, Campus Monte Carmelo, MG, Brazil). The experiment was conducted from November 2013 to March 2014 at UFU's Experimental Station on the Monte Carmelo campus, MG, Brazil. The statistical design consisted of randomized blocks with 47 treatments and four replications. Multivariate analyzes were performed for quantitative traits in 47 pepper access by principal component analysis. Means were compared by Scott-Knott test $(\alpha=0.05)$. Mature fruits were collected 120 days after transplant and used to determine titratable acidity (TA), total soluble solids (SS), $\mathrm{pH}$ and SS/TA. There was genetic variability among accessions. The 47 accessions showed high soluble solids content of $9.08^{\circ}$ Brix, acidity of $0.22, \mathrm{pH}$ of 5.50 and an SS/TA ratio of 33.8. This last characteristic is of great importance in the food processing industry. UFU accession 28 has high levels of SS and TA and is therefore a candidate for Pepper breeding programs that target the needs of the food processing industry.
\end{abstract}

KEYWORDS: Active germplasm bank. Capsicum spp. Quantitative descriptors. Genetic divergence.

\section{INTRODUCTION}

Peppers (Capsicum spp., Solanaecae family) are one of the most important vegetable crops in Brazil, especially in economic terms (Reifschneider 2000, Echer et al. 2002, Ribeiro et al. 2008). Special effort should be given to preserving some pepper species due to their national origin and distribution throughout Brazil (Reifschneider 2000). Moreover, genetic erosion within this species underlines the need for research that aims to preserve and characterize this national genetic resource.

Agricultural expansion and indiscriminate land use in Brazil may lead to the extinction of many wild species that include members of the Capsicum genus (Reifschneider 2000, Ribeiro et al 2008). One strategy for preserving genetic resources that are at risk of extinction is the creation of public, private, national and international germplasm banks. Hence, in 2013, the Germplasm Bank of Capsicum spp. was created at the Federal University of Uberlândia-UFU, Monte Carmelo Campus that currently contains more than 250 registered accessions.

Plant breeders have mostly focused on obtaining cultivars that are resistant to pests and diseases. Recently, however, the food processing industry has shown increasing interest in breeding programs that focus on the physical and chemical characteristics of pepper fruits (Ribeiro et al. 2008) that may significantly strengthen the supply chain. Registered pepper cultivars are scarce and no varieties are available for direct use by farmers that are specifically suitable for processing, especially regarding characteristics such as total soluble solids, titratable acidity, the SS/TA ratio and $\mathrm{pH}$. Detailed characterization of genetic diversity in this genus may encourage future breeding programs (Geleta et al. 2005, Neitzke et al. 2010, Ferrão et al. 2011, Faria et al. 2012).

Its was evaluated genetic variability in the physical and chemical characteristics of fruit from various pepper accessions in the Capsicum Germplasm Bank at the Federal University of Uberlândia-UFU.

\section{MATERIAL AND METHODS}

Forty-seven accessions were evaluated from the Germplasm Bank of Capsicum spp. at the Federal University of Uberlândia-UFU, Monte Carmelo Campus, MG, Brazil. Currently, the bank has 250 accessions that have been acquired through donation, collection and purchase at farmers' 
markets. All accessions are held at the Laboratory of Seed and Genetic Resource Analysis, UFU (LAGEN, Laboratory of Genetic Resources/UFU). This genetic material includes part of the pepper biodiversity in the Alto Paranaíba and Triângulo Mineiro regions of Minas Gerais state that are home to hundreds of small-scale pepper producers.

Table 1. Description of some of the peppers in the Germplasm Bank of Capsicum spp at the Federal University of Uberlandia-UFU, Monte Carmelo Campus, MG, Brazil, 2015.

\begin{tabular}{lll}
\hline Accession & Fruit Color & Origin \\
\hline UFU 1 & Red & Estrela do Sul, MG, Brazil \\
UFU 2 & Red & Estrela do Sul, MG, Brazil \\
UFU 3 & Red & Estrela do Sul, MG, Brazil \\
UFU 6 & Red & Estrela do Sul, MG, Brazil \\
UFU 7 & Red & Monte Carmelo, MG, Brazil \\
UFU 8 & Red & Monte Carmelo, MG, Brazil \\
UFU 9 & Red & Estrela do Sul, MG, Brazil \\
UFU 10 & Red & Estrela do Sul, MG, Brazil \\
UFU 12 & Yellow & Estrela do Sul, MG, Brazil \\
UFU 13 & Yellow & Estrela do Sul, MG, Brazil \\
UFU 14 & Red & Uberlândia, MG, Brazil \\
UFU 15 & Yellow & Estrela do Sul, MG, Brazil \\
UFU 16 & Yellow & Estrela do Sul, MG, Brazil \\
UFU 19 & Red & Uberlândia, MG, Brazil \\
UFU 20 & Yellow & São Felix, MG, Brazil \\
UFU 21 & Yellow & Estrela do Sul, MG, Brazil \\
UFU 23 & Yellow & Uberlândia, MG, Brazil \\
UFU 24 & Red & Monte Carmelo, MG, Brazil \\
UFU 26 & Red & Monte Carmelo, MG, Brazil \\
UFU 27 & Yellow & Perdizes, MG, Brazil \\
UFU 28 & Red & Coromandel, MG, Brazil \\
UFU 30 & Red & Perdizes, MG, Brazil \\
UFU 31 & Red & São Felix, MG, Brazil \\
UFU 32 & Red & Perdizes, MG, Brazil \\
UFU 33 & Red & Perdizes, MG, Brazil \\
UFU 34 & Red & Perdizes, MG, Brazil \\
UFU 36 & Purple & Monte Carmelo, MG, Brazil \\
UFU 37 & Red & Perdizes, MG, Brazil \\
UFU 38 & Red & Perdizes, MG, Brazil \\
UFU 39 & Red & Uberlândia, MG, Brazil \\
UFU 40 & Red & Estrela Do Sul, MG, Brazil \\
UFU 41 & Yellow & Estrela Do Sul, MG, Brazil \\
UFU 44 & Yellow & Monte Carmelo, MG, Brazil \\
UFU & Monte Carmelo, MG, Brazil \\
Uferlândia, MG, Brazil \\
Rede Carmelo, MG, Brazil
\end{tabular}




\begin{tabular}{lll} 
UFU 53 & Red & Monte Carmelo, MG, Brazil \\
UFU 54 & Laranja & Uberlândia, MG, Brazil \\
UFU 55 & Red & Monte Carmelo, MG, Brazil \\
UFU 56 & Red & Chapada de Minas, MG, Brazil \\
UFU 58 & Yellow & Monte Carmelo, MG, Brazil \\
UFU 59 & Red & São Felix, MG, Brazil \\
UFU 61 & Red & Monte Carmelo, MG, Brazil \\
UFU 62 & Red & Monte Carmelo, MG, Brazil \\
UFU 63 & Purple & Estrela do Sul, MG, Brazil \\
UFU 66 & Yellow & São Felix, MG, Brazil \\
UFU 68 & Red & Monte Carmelo, MG, Brazil \\
\hline
\end{tabular}

The trial was conducted at the Horticultural Experiment Station, UFU (Estação Experimental de Hortaliças da UFU) (altitude 873 m, 18²4'43,19"S, $47^{\circ} 29$ '55, $8^{\prime \prime} \mathrm{W}$, humid temperate climate with hot summers and dry winters). Sowing took place on November 21, 2013 in 200-cell polystyrene trays filled with a commercial, coconut-fiber based substrate. The trays were kept in a gable-roofed greenhouse $(7 \times 4 \mathrm{~m})$ with a ceiling height of 3 meters and covered by a transparent 150-micron polyethylene film activated against ultraviolet rays. The seedlings were transplanted 60 days after sowing (after the appearance of 4 to 6 sets of leaves). Twenty seedlings of each accession were transplanted into individual rows (spaced $1.0 \times 0.7$ m) in each plot for a total of $1316 \mathrm{~m}^{2}$ with $14 \mathrm{~m}^{2}$ in each experimental unit.

Before transplanting, the experimental site was prepared by harrowing once and disking twice. The soil had the following characteristics: $\mathrm{pH}\left(\mathrm{H}_{2} \mathrm{O}\right)$ $=5.9 ;$ available $\mathrm{P}=30.1 \mathrm{mg} \cdot \mathrm{dm}^{-3} ; \mathrm{K}=0.22$ cmolc. $\mathrm{dm}^{-3} ; \mathrm{Ca}^{+2}=2.8$ cmolc. $\mathrm{dm}^{-3} ; \mathrm{Mg}=1.0$ cmolc. $\mathrm{dm}^{-3}$; exchangeable $\mathrm{H}^{+} \mathrm{Al}=3.40 \mathrm{cmolc} . \mathrm{dm}^{-}$ 3; organic matter $=4.2 \mathrm{dag} \mathrm{Kg}^{-1} ; \mathrm{SMP}=3.40$; Aluminum $=0.0 \mathrm{cmolc} \cdot \mathrm{dm}^{-3} ; \mathrm{CEC}$ pH $7.0=7.42$ cmolc. $\mathrm{dm}^{-3}$; base saturation of CEC $(\mathrm{pH} 7.0)=54$ $\%$; Al saturation of the effective $\mathrm{CEC}=0$; Copper $=$ $2.3 \mathrm{mg} \cdot \mathrm{dm}^{-3} ;$ Zinc $=6.6 \mathrm{mg} \cdot \mathrm{dm}^{-3}$ and Manganese $=$ $6.6 \mathrm{mg} \cdot \mathrm{dm}^{-3}$. Crop treatments were performed as recommended for peppers (Filgueira 2000; Ribeiro et al. 2008).

Fully mature fruits were harvested 120 days after transplant for physiochemical characterization. These samples were then used to determine titratable acidity (TA), total soluble solids (TSS), $\mathrm{pH}$ and SS/TA. Soluble solids (SS) were determined using a digital refractometer according to the AOAC methodology (2002) and expressed as ${ }^{\circ}$ Brix. Titratable acidity was determined by diluting $1 \mathrm{~g}$ of pulp in $50 \mathrm{~mL}$ of distilled water and then titrating with a $\mathrm{NaOH}$ solution $(0.1 \mathrm{~N})$. These results were expressed as a percentage of citric acid (Ial 1985). After processing, $\mathrm{pH}$ was measured directly in the pulp using a potentiometer (Mettler DL 12 model) calibrated with pH 4 and 7 buffers AOAC (2002).

The statistical design was randomized blocks (RBD) with 47 treatments (accessions) and four repetitions.

$\mathrm{Y}_{\mathrm{ij}}=\mu+\mathrm{b}_{\mathrm{j}}+\mathrm{t}_{\mathrm{i}}+\mathrm{e}_{\mathrm{ij}}$ where:

$Y_{i j}$ observation of the $i$-th genotype in the $j$-th block;

$\mu$ - fixed effect of the general average;

$b_{j}$ - random effect of the $j$-th block;

$t_{i}$ - fixed effect of the $i$-th genotype (treatments);

$\mathrm{e}_{\mathrm{ij}}$ - mean experimental error.

Means were submitted to analysis of variance, which consisted of comparing the sum of mean squares by the F test $(\alpha=0.05)$. A Scott-Knott test $(\alpha=0.05)$ was used to compare the means of soluble solids, titratable acidity and the SS/TA ratio. In order to unite information from these variables, multivariate analysis was performed through principle components using the Genes software (Cruz 2008).

\section{RESULTS AND DISCUSSION}

There was a significant difference $(\mathrm{p}>0.05)$ among the 47 accessions (especially UFU 28) regarding soluble solids (SS), titratable acidity and the SS/TA ratio (Table 2). 
Table 2. Physiochemical characterization of pepper accessions from the Capsicum spp. Germplasm Bank at the Federal University of Uberlandia (Universidade Federal de Uberlândia-UFU) - Monte Carmelo Campus, 2015

\begin{tabular}{|c|c|c|c|c|c|}
\hline Accession & TA (\% citric acid) & SS ( ${ }^{\circ}$ brix $)$ & Temperature ${ }^{\circ} \mathrm{C}$ & SS/TA ratio & $\mathrm{Ph}$ \\
\hline UFU 1 & $0.354 \mathrm{c}$ & $9.238 \mathrm{~h}$ & 22.5 & $26.108 \mathrm{j}$ & 5.52 \\
\hline UFU 2 & $0.299 \mathrm{e}$ & $11.468 \mathrm{c}$ & 22.1 & $38.380 \mathrm{f}$ & 5.32 \\
\hline UFU 3 & $0.387 \mathrm{~b}$ & $10.280 \mathrm{e}$ & 22.6 & $27.592 \mathrm{j}$ & 5.58 \\
\hline UFU 6 & $0.328 \mathrm{~d}$ & $11.813 \mathrm{~b}$ & 22.6 & $36.113 \mathrm{~g}$ & 5.57 \\
\hline UFU 7 & $0.189 \mathrm{~h}$ & $8.938 \mathrm{~h}$ & 22.6 & $47.384 \mathrm{c}$ & 5.58 \\
\hline UFU 8 & $0.151 \mathrm{i}$ & $8.175 \mathrm{j}$ & 22.8 & $54.177 \mathrm{~b}$ & 5.81 \\
\hline UFU 9 & $0.238 \mathrm{~g}$ & $10.000 \mathrm{f}$ & 22.3 & $42.054 \mathrm{e}$ & 5.45 \\
\hline UFU 10 & $0.197 \mathrm{~h}$ & $8.030 \mathrm{j}$ & 22.6 & $40.728 \mathrm{f}$ & 5.69 \\
\hline UFU 12 & $0.242 \mathrm{~g}$ & $8.938 \mathrm{~h}$ & 21.6 & $36.943 \mathrm{~g}$ & 5.53 \\
\hline UFU 13 & $0.332 \mathrm{~d}$ & $8.655 \mathrm{i}$ & 21.6 & $26.092 \mathrm{j}$ & 5.44 \\
\hline UFU 14 & $0.365 \mathrm{c}$ & $12.088 \mathrm{~b}$ & 21.8 & $33.105 \mathrm{~h}$ & 5.43 \\
\hline UFU 15 & $0.297 \mathrm{e}$ & 8.748 i & 22.7 & $29.494 \mathrm{i}$ & 5.48 \\
\hline UFU 16 & $0.283 \mathrm{f}$ & 4.0001 & 22.1 & $14.171 \mathrm{~m}$ & 5.82 \\
\hline UFU 19 & $0.369 \mathrm{c}$ & $8.500 \mathrm{i}$ & 22.4 & $23.008 \mathrm{k}$ & 5.27 \\
\hline UFU 20 & $0.276 \mathrm{f}$ & $9.593 \mathrm{~g}$ & 22.4 & $34.784 \mathrm{~h}$ & 5.64 \\
\hline UFU 21 & $0.281 \mathrm{f}$ & $8.560 \mathrm{i}$ & 22.1 & $30.465 \mathrm{i}$ & 5.42 \\
\hline UFU 23 & $0.276 \mathrm{f}$ & $6.060 \mathrm{k}$ & 21.9 & 21.9751 & 5.58 \\
\hline UFU 24 & $0.195 \mathrm{~h}$ & $8.625 \mathrm{i}$ & 22.3 & $44.203 \mathrm{~d}$ & 5.42 \\
\hline UFU 26 & $0.340 \mathrm{~d}$ & $9.905 \mathrm{f}$ & 22.8 & $29.174 \mathrm{i}$ & 5.61 \\
\hline UFU 27 & $0.407 \mathrm{~b}$ & $8.155 \mathrm{j}$ & 22.3 & 20.0291 & 5.46 \\
\hline UFU 28 & $0.444 \mathrm{a}$ & $12.623 \mathrm{a}$ & 22.4 & $28.456 \mathrm{i}$ & 5.52 \\
\hline UFU 30 & $0.424 \mathrm{a}$ & $10.218 \mathrm{e}$ & 22.8 & $24.094 \mathrm{k}$ & 5.53 \\
\hline UFU 31 & $0.234 \mathrm{~g}$ & $7.813 \mathrm{j}$ & 22.8 & $33.366 \mathrm{~h}$ & 5.76 \\
\hline UFU 32 & $0.213 \mathrm{~h}$ & $8.405 \mathrm{i}$ & 23.1 & $39.398 \mathrm{f}$ & 5.62 \\
\hline UFU 33 & $0.273 \mathrm{f}$ & $9.935 \mathrm{f}$ & 22.2 & $36.445 \mathrm{~g}$ & 5.48 \\
\hline UFU 34 & $0.250 \mathrm{~g}$ & $7.955 \mathrm{j}$ & 22.7 & $31.851 \mathrm{i}$ & 5.65 \\
\hline UFU 36 & $0.262 \mathrm{~g}$ & $8.780 \mathrm{i}$ & 23.0 & $35.580 \mathrm{~h}$ & 5.41 \\
\hline UFU 37 & $0.187 \mathrm{~h}$ & $8.750 \mathrm{i}$ & 22.3 & $46.712 \mathrm{c}$ & 5.92 \\
\hline UFU 38 & $0.351 \mathrm{c}$ & $8.938 \mathrm{~h}$ & 21.8 & $25.447 \mathrm{j}$ & 5.30 \\
\hline UFU 39 & $0.299 \mathrm{e}$ & $9.000 \mathrm{~h}$ & 21.7 & $30.081 \mathrm{i}$ & 5.42 \\
\hline UFU 40 & $0.264 \mathrm{f}$ & $9.438 \mathrm{~g}$ & 22.3 & $35.739 \mathrm{~g}$ & 5.59 \\
\hline UFU 41 & $0.355 \mathrm{c}$ & $8.467 \mathrm{i}$ & 22.9 & $23.865 \mathrm{k}$ & 5.09 \\
\hline UFU 44 & $0.075 \mathrm{j}$ & $8.063 \mathrm{j}$ & 22.2 & $107.884 \mathrm{a}$ & 5.84 \\
\hline UFU 49 & $0.208 \mathrm{~h}$ & $9.405 \mathrm{~g}$ & 21.9 & $45.188 \mathrm{c}$ & 5.53 \\
\hline UFU 50 & $0.243 \mathrm{~g}$ & $8.718 \mathrm{i}$ & 22.7 & $35.837 \mathrm{~g}$ & 5.79 \\
\hline UFU 51 & $0.363 \mathrm{c}$ & $10.013 \mathrm{f}$ & 22.8 & $27.588 \mathrm{j}$ & 5.23 \\
\hline UFU 53 & $0.409 \mathrm{~b}$ & $10.468 \mathrm{~d}$ & 22.2 & $25.627 \mathrm{j}$ & 5.33 \\
\hline UFU 54 & $0.276 \mathrm{f}$ & $10.710 \mathrm{~d}$ & 22.1 & $38.836 \mathrm{f}$ & 5.48 \\
\hline UFU 55 & $0.328 \mathrm{~d}$ & $8.655 \mathrm{i}$ & 22.9 & $26.450 \mathrm{j}$ & 5.24 \\
\hline UFU 56 & $0.364 \mathrm{c}$ & $8.613 \mathrm{i}$ & 22.9 & $23.646 \mathrm{k}$ & 5.43 \\
\hline
\end{tabular}




\begin{tabular}{llllll} 
UFU 58 & $0.277 \mathrm{f}$ & $9.655 \mathrm{~g}$ & 21.6 & $34.828 \mathrm{~h}$ & 5.28 \\
UFU 59 & $0.355 \mathrm{c}$ & $8.030 \mathrm{j}$ & 22.4 & $22.612 \mathrm{k}$ & 5.22 \\
UFU 61 & $0.255 \mathrm{~g}$ & $7.688 \mathrm{j}$ & 23.2 & $30.152 \mathrm{i}$ & 6.06 \\
UFU 62 & $0.239 \mathrm{~g}$ & $8.125 \mathrm{j}$ & 22.8 & $33.946 \mathrm{~h}$ & 5.45 \\
UFU 63 & $0.270 \mathrm{f}$ & $9.688 \mathrm{~g}$ & 23.0 & $35.804 \mathrm{~g}$ & 5.43 \\
UFU 66 & $0.377 \mathrm{c}$ & $9.125 \mathrm{~h}$ & 21.9 & $24.189 \mathrm{k}$ & 5.14 \\
UFU 68 & $0.320 \mathrm{~d}$ & $9.718 \mathrm{~g}$ & 21.6 & $30.433 \mathrm{i}$ & 5.23 \\
\hline
\end{tabular}

Means followed by the same letter within a column do not differ by the Scott-Knott test at 5\% probability.

Significant differences were found among SS values. For example, UFU 28 stood out with 12.623 Brix, suggesting this variety's potential for applications in the food processing industry. UFU 06 and UFU 14 showed high SS values (11.813 and $12.088{ }^{\circ}$ Brix, respectively), indicating their potential for breeding programs. In contrast, accession UFU 16 had a low SS value $\left(4.0^{\circ}\right.$ Brix), which might indicate potential for crosses with other varieties in order to increase SS. The magnitude between the highest and lowest SS values among all evaluated accessions (UFU 28 versus 16 UFU) was a highly divergent $68.31 \%$. The SS values obtained in the present study were higher than those found by Lannes et al. (2007), which varied from 6 to 10 ${ }^{\circ}$ Brix. A high level of soluble solids in vegetable crops is important to the food processing industry because it indicates higher final yield (REGO et al., 2009).

Among the 47 accessions evaluated, TA varied significantly from 0.444 to $0.0747 \%$ (UFU 28 and UFU 44, respectively) for a total oscillation of $83.18 \%$. UFU 30 and UFU 28 (0.424 and $0.444 \%$, respectively) were the most prominent. A high TA level in fruit is important because it is reflected in preservation and deterioration (OLIVEIRA et al. 1999). The high values found in UFU 30 and UFU 28 were slightly lower than those found by Crisóstomo et al. (2008) in the fruit of the Tabasco cultivar $(0.48 \%)$. In contrast, the TA values of UFU 30 and UFU 28 were higher than those found by Valverde (2011) $(0.03 \%)$.

The SS/TA ratio varied among the accessions evaluated. UFU 44 had the highest ratio at 107.884 (Table 2). The SS/TA results found in the current study were higher than those found by Crisóstomo et al. (2008), which averaged 47.93. The ratio between total soluble solids and titratable acidity is related to the balance between sugar and acid and therefore is an important indicator of flavor.

The $\mathrm{pH}$ levels varied little among progenies with a low of 5.13 and a high of 5.57 (Table 2) for a total variation of $7.89 \%$. These $\mathrm{pH}$ values were higher than those found by Crisóstomo et al. (2008), which averaged 4.75 in fruit of the cultivar "Tabasco" grown in the Brazilian state of Ceará. Valverde (2011) found a slightly acid average value (5.48) for the malgueta pepper in natura. This value was similar to that found in the present study. $\mathrm{pH}$ is an important indicator of the potential for and rapidity of deterioration from the growth of hazardous microorganisms.

The 47 accessions in the current study showed an average soluble solids level of 9.08 ${ }^{\circ}$ Brix, titratable acidity of $0.22, \mathrm{pH}$ of 5.50 and SS/TA of 33.83, which is of great importance to the food processing industry. UFU 28 had high SS and TA values, which suggest that this accession has potential for pepper breeding programs that target the needs of industry.

Principal component analysis (Figure 1) reinforced the results of the means test (Table 2) that showed the genetic variability of the accessions tested. Four distinct groups are evident (Figure 1). The first group consists of only UFU 44, which had the lowest TA value $(0.0747 \%)$ and the highest SS/TA ratio (107.884\%) of all the tested accessions (Table 2). The second group consisted of UFU 2, UFU 6, UFU 14, and UFU 28. The third group was represented by UFU 1, UFU 3, UFU 7, UFU 8, UFU 9, UFU 10, UFU 12, UFU 13, UFU 15, UFU 19 , UFU 20, UFU 21, UFU 24, UFU 26, UFU 27 , UFU 30, UFU 31,UFU 32, UFU 33, UFU 34, UFU 36, UFU 37, UFU 38, UFU 39, UFU 40, UFU 41, UFU 49, UFU 50, UFU 51, UFU 53, UFU 54, UFU 55, UFU 56,UFU 58, UFU 59, UFU 61, UFU 62, UFU 63, UFU 66 and UFU68. Finally, the fourth group consisted of UFU 16 and UFU 23. 


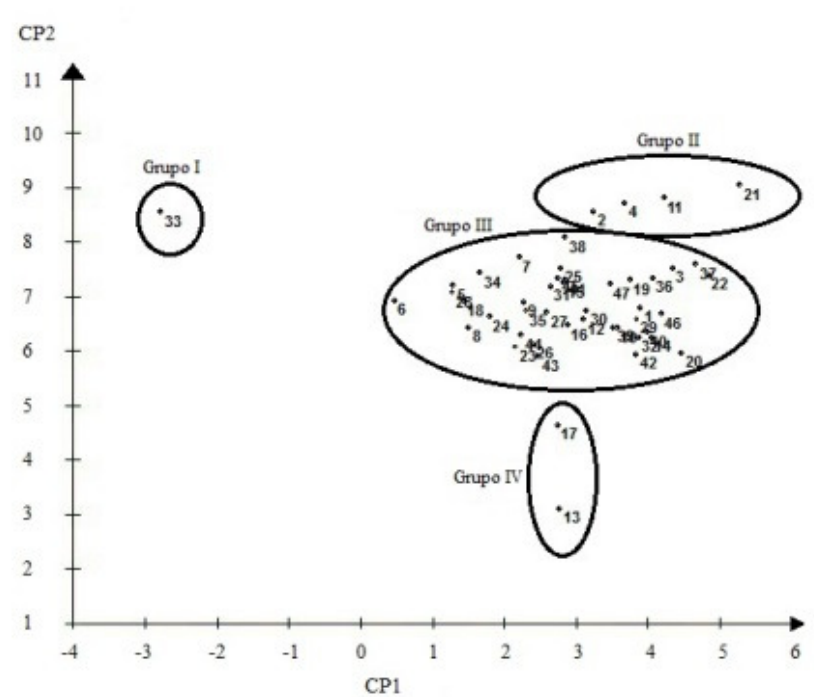

Figure 1. Graphic dispersion of 47 subsamples of Capsicum spp. based on the first two variables created, established by the linear combination of three physiochemical fruit characteristics. Monte Carmelo, UFU, 2015. Numbers are associated to accessions as follows: 1- UFU 1, 2- UFU 2, 3- UFU 3, 4UFU 6, 5- UFU 7, 6- UFU 8 ,7- UFU 9, 8- UFU 10, 9- UFU 12,10- UFU 13, 11-UFU-14, 12-UFU 15, 13- UFU 16, 14- UFU 19, 15- UFU 20,16- UFU 21, 17- UFU-23, 18- UFU 24, 19 - UFU 26,20UFU 27, 21- UFU-28, 22- UFU 30, 23- UFU 31, 24-UFU 32, 25- UFU 33, 26-UFU 34, 27-UFU 36, 28-UFU 37,29- UFU 38, 30-UFU 39, 31-UFU 40, 32-UFU 41, 33-UFU 44, 34-UFU 49, 35-UFU 50, 36-UFU 51, 37-UFU 53, 38-UFU 54, 39-UFU 55,40- UFU 56,41-UFU 58, 42-UFU 59,43- UFU 61, 44-UFU 62, 45-UFU 63, 46-UFU 66 and 47- UFU68

The efficiency of using principal component analysis with accessions of the Capsicum genus has been confirmed by various authors and is widely used (MONTEIRO et al. 2010, NEITZKE et al. 2010, FERRÃO et al. 2011, FARIA et al. 2012). In the present study it was also possible to efficiently detect divergence among accessions. The genetic dissimilarity revealed among the accessions could be further explored by obtaining homozygous lines and subsequent hybrid combinations targeting heterosis (MALUF, 2001; RIBEIRO et al. 2008, RÊGO et al. 2009).

Its was determined that the capsicum germplasm bank at the Federal University of Uberlandia (Universidade Federal de Uberlândia) has sufficient genetic diversity for exploration in breeding programs that target the needs of the food processing industry.

\section{CONCLUSION}

There was genetic variability among accessions performed. The genetic dissimilarity among the accessions evaluated in the current study indicates potential for pepper breeding programs, especially those that target the needs of the food processing industry.

\section{ACKNOWLEDGEMENTS}

We are grateful for financial support in the form of scholarships from the Brazilian institutions CNPq and FAPEMIG. We are also grateful for use of the infrastructure necessary for our research provided by the Federal University of Uberlandia Monte Carmelo Campus (Universidade Federal de Uberlândia - UFU, Campus Monte Carmelo/MG).

RESUMO: O objetivo do trabalho foi avaliar a variabilidade genética entre acessos de pimenta para características físico-químico de fruto. Os acessos de pimenta utilizados são provenientes do Banco de Germoplasma da Universidade Federal de Uberlândia. O experimento foi conduzido entre novembro de 2013 a março de 2014, na Estação Experimental de Hortaliças da UFU, campus Monte Carmelo. O delineamento estatístico utilizado foi em blocos casualizados com 47 tratamentos e quatro repetições. Foi realizada análise multivariada para caracteres quantitativos utilizando análise de componentes principais. As médias foram comparadas pelo teste Scott-Knott $(\alpha=0,05)$. Frutos maduros foram colhidos 120 dias após o transplante e utilizados para determinar a acidez titulável (AT), sólidos solúveis totais (SST), pH e relação SS / AT. Houve variabilidade genética entre os acessos. Os 47 acessos apresentaram alto teor de 
sólidos solúveis de $9,08^{\circ}$ Brix, acidez de 0,22 , pH de 5,50 e uma relação SS / AT de 33,8. Esta última característica é de grande importância na indústria de processamento de alimentos. O acesso UFU 28 revelou níveis elevados de SS e AT se destacando entre os demais. Os acessos que destacaram são promissores para fomentar futuros programas de melhoramento genético de pimenta com boas características para indústria de processamento.

\section{genética.}

PALAVRAS-CHAVE: Capsicum spp. Banco ativo de germoplasma. Descritores quantitativos. Divergência

\section{REFERENCES}

AOAC-ASSOCIATION OF OFFICIAL ANALYTICAL CHEMISTS. Official methods of analysis of AOAC international. 17. ed. Washington, 2002

CRISÓSTOMO, J. R; FURTADO, R. F; BARRETO, P. D; MIRANDA, F. R. 2008. Cultivo de Pimenta Tabasco no Ceará. In: MELO, M. A. R. (Ed.). Pesquisa e Desenvolvimento para o Agronegócio Pimenta no Ceará. Fortaleza: Embrapa Agroindústria Tropical. p. 1-36.

CRUZ, C. D. Programa genes: análise multivariada e simulação. Viçosa: UFV, 2008. 175 p.

CRUZ, C. D; CARNEIRO, P. C. S. Modelos biométricos aplicados ao melhoramento genético. 2. ed. Viçosa: UFV, 2006. v. 2.

CRUZ, C. D. 2006. Programa Genes: Estatística experimental e matrizes. Viçosa: UFV. 285p.

ECHER, M. M; FERNANDES, M. C. A; RIBEIRO, R. L. D; PERACCHI, A. L. Avaliação de genótipos de Capsicum para resistência ao acaro branco. Horticultura Brasileira, Brasília, v. 20, n. 2, p. 217-221. 2002. http://dx.doi.org/10.1590/S0102-05362002000200020

FARIA, P. N.; CECON, P. R.; SILVA, A. R.; FINGER, F. L.; SILVA, F. F.; CRUZ, C. D.; SÁVIO, F. L. Métodos de agrupamento em estudo de divergência genética de pimentas. Horticultura Brasileira, Brasília, v. 30, n. 3 p. 428-432. 2012. http://dx.doi.org/10.1590/S0102-05362012000300012

FERRÃO, L. F. V.; CECON, P. R.; FINGER, F. L.;. SILVA, F. F.; PUIATTI, M. Divergência genética entre genótipos de pimenta com base em caracteres morfoagrônomicos. Horticultura Brasileira, Brasília, v. 29, n. 3, p. 354-358. 2011. http://dx.doi.org/10.1590/S0102-05362011000300016

FILGUEIRA, F. A. R. 2008. Novo Manual de Olericultura: Agrotecnologia moderna na produção e comercialização de hortaliças. Viçosa: UFV. 421p.

GELETA, L. F.; LABUSCHAGNE, M. T.; VILJOEN, C. D. Genetic variability in pepper (Capsicum annuum L.) estimated by morphological data and amplified fragment length polymorphism markers. Biodiversity and Conservation, v. 14, p. 361-375. 2005. http://dx.doi.org/10.1007/s10531-004-16699

IAL. INSTITUTO ADOLFO LUTZ. Normas analíticas, métodos químicos e físicos para análise de alimentos. São Paulo: IAL, 1985. v. 1, 371p

LANNES, S. D.; FINGER, F. L.; SCHUELTER D. R.; CASALI, V. W. D. Growth and quality of Brazilian acessions of Capsicum chinense fruits. Scientia Horticulturae v. 112 p. 266-270. 2007.

http://dx.doi.org/10.1016/j.scienta.2006.12.029

MALUF, W. R. 2001. Heterose e emprego de híbridos $F_{1}$ em hortaliças. In: NASS, L. L; VALOIS, A. C. C.; MELO, I. S.; VALADARES, M. C. (eds). Recursos genéticos e melhoramento: plantas. Rondonópolis: Fundação MT. p. 650-671. 
NEITZKE, R. S.; BARBIERI, R. S.; HEIDEN, G.; CASTRO, C. M. Divergência genética entre variedades locais de Capsicum baccatum utilizando caracteres multicategóricos. Magistra, v. 20, n. 3, p. 249-255,2008.

NEITZKE, R. S.; BARBIERI, R. L.; RODRIGUES, M. W.; CORRÊA, I. V.; CARVALHO, F. I. F. Dissimilaridade genética entre acessos de pimenta com potencial ornamental. Horticultura Brasileira, Brasília,v. 28 p. 47-53. 2010. http://dx.doi.org/10.1590/S0102-05362010000100009

OLIVEIRA, M. E. B.; BASTOS, M. S. R.; FEITOSA, T.; BRANCO, M. A. A. C.; SILVA, M. G. G. Avaliação de parâmetros de qualidade físico-químicos de polpas congeladas de acerola, cajá e caju. Ciência e Tecnologia de Alimentos, Campinas, v. 19, n. 3, set. /dez. p. 326-332, 1999.

RÊGO, E. R.; RÊGO, M. M.; FINGER, F. L.; CRUZ, C. D.; CASALI, V. W. D. A diallel study of yield components and fruit quality in chilli peppers (Capsicum baccatum). Euphytica, v. 168, p. 275-287.2009.

REIFSCHNEIDER, F. J. B. (Ed.). Capsicum: pimentas e pimentões no Brasil. Brasília: Embrapa Comunicação para Transferência de Tecnologia/Embrapa Hortaliças. 113p, 2000.

RIBEIRO, C. S. C.; REIFSCHNEIDER, F. J. B. Genética e melhoramento. In: RIBEIRO, C. S. C.; LOPES, C. A.; CARVALHO, S. I. C.; HENZ, G. P.; REIFSCHNEIDER, F. J. B. Pimentas Capsicum. Brasília: Embrapa Hortaliças. p. $55-69,2008$.

VALVERDE, R. M. V. Composição bromatológica da pimenta malagueta in natura e processada em conserva. 2011. 54f. (Dissertação - Mestrado em Engenharia de Alimentos- Engenharia de Processos de Alimentos). UESB, Itapetinga-BA, 2011 